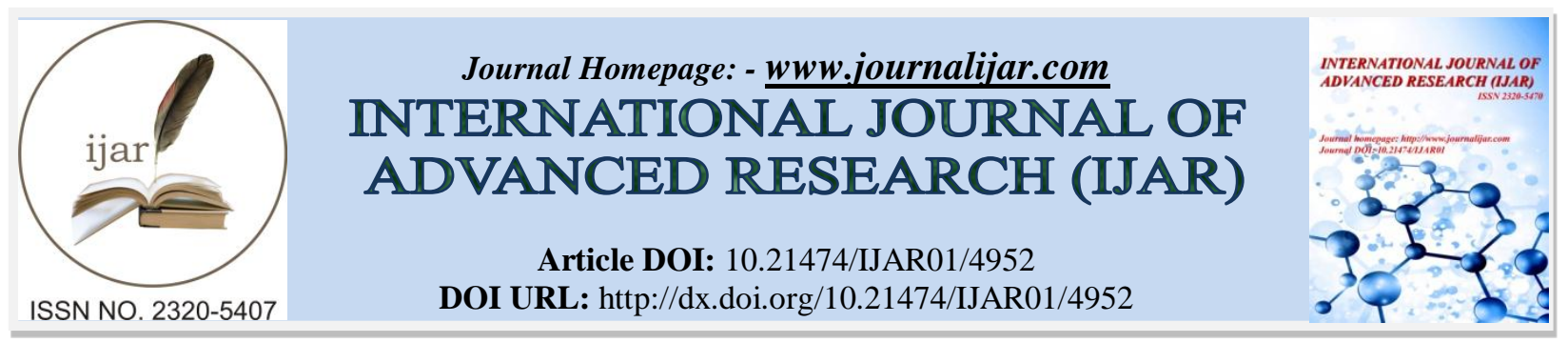

RESEARCH ARTICLE

\title{
PHYTOCHEMICAL SCREENING AND IN-VITRO ANTI-FUNGAL ACTIVITY OF "TRIDAX PROCUMBENS L.
}

\author{
"Y. Bhagyasri, N. Vinay reddy, M. Dattatrya, K. Divya and "N. Siva Subramanian. \\ Gland Institute Of Pharmaceutical science, Sy No.551, Shangri-La, Kothapet (v), Sivampet (m), Near Narsapur, \\ Medak (dist) Telangana.
}

\section{Manuscript Info}

(..........................

Manuscript History

Received: 25 May 2017

Final Accepted: 27 June 2017

Published: July 2017

Key words:-

Anti-fungal activity, Tridax procumbens

L, Phytoconstituents, Other activities.

\section{Abstract}

In this study, our focus is to evaluate the role of bioactive molecule present in the essential oil of Tridax procumbens $L$ fresh leaves against bacterial and fungal species. The essential oil and flavonoids of Tridax procumbens $L$." has a number of properties that are beneficial to human health and well being. It may be used in the pharmaceutical and cosmetic industries for the development of new drug formulation for treating bacterial and fungal infections and also for treating inflammation related diseases in a cheaper rate with fewer side effects. The results of study have shown that the ethyl acetate and ethanolic extracts obtained from the Tridax procumbens were active against at least one of the opportunistic fungi the results of this study have shown that the leaf and whole plant extraction of Tridax procumbens L." Have great potential as antibacterial agents in the treatment of infectious organism. Further, detailed investigation of the active compounds of the plant for the extract mechanism of action will contribute greatly to the development new pharmaceuticals.

Copy Right, IJAR, 2017,. All rights reserved.

\section{Introduction:-}

The demand on plant based therapeutics seems to increasing in both developing \& developed countries due to the growing recognistic that they are natural products, being non narcotic, having no side effects, easily available at affordable prices and sometimes the only source of health care available to the poor. Plants have been used in developing countries as alternative treatments to cure diseases. Plant extracts are source of many potent and powerful drugs and many plant extracts and essential oils isolated have been shown to posses biological activity in vitro and in vivo, which justifies research on plant based medicine focused on the characterization of antimicrobial activity of these plants [1]. Thus the use of medicinal plants in disease treatment and prevention can also be seen as prehistoric and their present use can be supported by the traditional optimization of their application in disease control. Medicinal uses of plants range from administration of roots, barks, stems, leaves and seed to the use of extracts from the [2]. These plant extracts a sources of many potent and powerful drugs (3). Brazil and india are example countries that have a diverse flora and rich tradition in the use of medicinal plants both as antibacterial and antifungal applications. The antimicrobial activity of mrdicinal plants evaluated against enteric food borne pathogen (4). Antibacterial activities of some medicinal plants were observed earlier (5). Almost, all the cultivated crops are infected by one or more pathogens causing economic losses. The majority of the diseases are caused by fungi, bacteria and viruses. Apart from cultural methods are widely used to control the diseases caused by these pathogens. 
More use of bactericides and fungicides like organomercurical, carbamates etc. have posed serious problem to human and environmental health [6]. So reasearch for natural bio-degradable source of bactericides and fungicides have always been quest for the researchers for control of bacterial and fungal disease of plants. Because of the present day public perception on pesticide contamination of foods especially the edible fruits, seeds, vegetables and oils, there is need for development of alternative economical and eco-friendly approaches for bacteria and fungal disease management. This could provide an alternative to the present day pollution problem of air, soil, water and residual effects of synthetic pesticides. with this view, the present investigation was undertaken to select plant extracts that could be effective in the development of new tools for the control of diseases caused by bacteria and fungi to the plants of economic importance. The major areas of drug from medicinal plants include disease conditions for which modern drugs are either unavailable or unsatisfactory (7) .Tridax procumbens is a common annual weed. In west Africa sub region and tropical zones of world like india is known as "coat buttons". Traditional medicine practitioners (TMPs) and tribal peoples of these areas use the leaves of plant as a remedy against sevseral ailments ranging conjunctivitis, diarrhoea and dysentery to wound healing and related inflammoatory conditions (8). Various studies have been carried out using plant extract of tridax procumbens in different solvents extraction such as total phenolics and antioxidant activity (9). Pharmacological evaluation (10),(11). Chemical profile (12), effect on lipopolysaccharide-induced hepatitis(13). Essential oil is so termed as they are believed to represent the very essence of odour and Flavour (14). There ia about three hundred essential oil in general use today by professional practitioners(15).Continuous damage has been encounted by viral, bacterial, parasitic and fungal contamination in our body. Essential oil plays a major role in protecting our body from this onslaught of pathogens, since immune system needs support and his essential oil can give the required endorsement(16). Essevelopment of drugs. ntial oil is also found to have wide use in pharmaceutical industries in de In this study, our focus is to evaluate the role of bioactive molecule present in the essential Oil of tridax procumbens fresh leaves agains bacterial and fungal species.
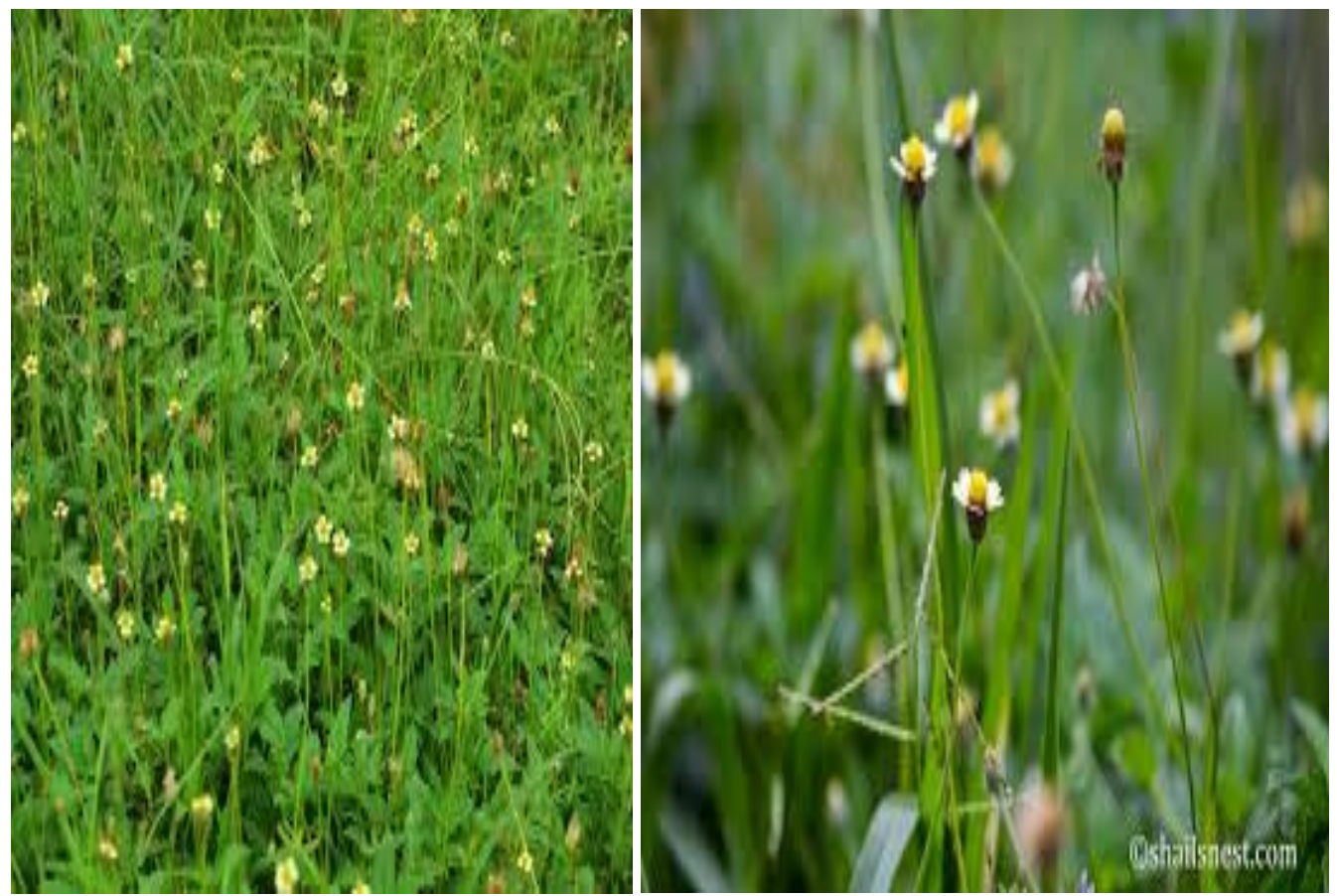

Plant profile:-

Scientific and biological classification of tridax procumbens

\begin{tabular}{|c|c|c|}
\hline Classification & Scientific name & Biological name \\
\hline Kingdom & Plantae & Plants \\
\hline Sub kingdom & Tracheobionta & Vascular plants \\
\hline Division & Spermatophyta & ---- \\
\hline Sub division & Mangnoliophyta & Flowering plants \\
\hline Class & Mangoliopsida & Dicotyledons \\
\hline Sub class & Asteridae & ---- \\
\hline
\end{tabular}




\begin{tabular}{|c|c|c|}
\hline Order & Asterales & Aster family \\
\hline Family & Asteraceae & Tridax \\
\hline Genus & Tridax 1 & Cocat buttons \\
\hline Species & Tridax procumbens 1 \\
\hline
\end{tabular}

\section{Distribution:-}

The plant is native of tropical America and neutralized in tropical asia, Africa, australia, and india. It is a wild herb distributed throughout india. It is also found along roadsides, waste grounds, dikes, riverbanks, meadows and dunes.

\section{Propagation:-}

It is not possible to micropropagate it through vegetative means for example cuttings. Propagation through seeds causes variations. Methods have been developed for its ex-situ conservation through micro propagation (17). Its wide distribution is due to spreading stems and abundant seed production (18).

Parts USED:-

Whole plant (leaf, stem and flower) is used to cure different ailments.

\section{Morphological Features:-}

Tridax procumbens $L$. is a small perrenial herb having short, blade like leaves. Transverse section studies of leaf along the midrib stem and roots were done.

Macroscopic of Tridax procumbens $L$.

\begin{tabular}{|c|c|}
\hline PARTS & OBSERVATION \\
\hline parts & Leaves \\
\hline Arrangement & Opposite \\
\hline size & L-7 cm long, 1-4 cm wide \\
\hline shape & Green \\
\hline colour & Characteristic \\
\hline Odour & Acrid \\
\hline Taste & Rough \& scabrous \\
\hline Appearance & Irregularly toothed \\
\hline Margin & Acute \\
\hline Apex & Wedge- shaped \\
\hline base & Short \\
\hline Petiole & Short \\
\hline Texture & easy \\
\hline Fracture & \\
\hline
\end{tabular}

\section{Histological Studies Of Tridax Procumbens L:-}

Transverse section of the whole plant of tridax procumbens was studied. The section of leaf shows single layered upper epidermis consisting of polygonal tabular cells about 40-70 mewm by 15 to 30 mew m with asingle layer of cylindrical palisade cells about 18 to 30 mew m wide and 60 to 70 mew m long, spongy parenchyma 2-4 layered, cells polyhedral or isodiameteric in shape.

Preliminary Phytochemical Screening Of Various Extracts Of The Whole Plant Of Tridax Procumbens L:-

The coarsely powdered plant material was subjected to extraction by solvents with increasing polarity and the dried extracts were subjected to phytochemical studies using standard test procedures.

Phytochemical Screening:-

\begin{tabular}{|c|c|c|c|c|}
\hline S.NO & CONSTITUENTS & ETHANOL & AQUEOUS & ETHYL ACETATE \\
\hline 1 & alkaloids & $(-)$ & $(-)$ & $(+)$ \\
\hline 2 & Anthraquinonine glycosides & $(-)$ & $(-)$ & $(+)$ \\
\hline 3 & flavonoids & $(+)$ & $(-)$ & $(+)$ \\
\hline 4 & Phenolic groups & $(+)$ & $(+)$ & $(+)$ \\
\hline 5 & saponins & $(+)$ & $(+)$ & $(+)$ \\
\hline 6 & tannins & $(+)$ & $(+)$ & $(+)$ \\
\hline
\end{tabular}




\begin{tabular}{|c|c|c|c|c|}
\hline 7 & steriods & $(+)$ & $(+)$ & $(+)$ \\
\hline 8 & carbohydrates & $(+)$ & $(+)$ & $(+)$ \\
\hline
\end{tabular}

(+) indicates presence

(-) indicates absence

\section{Chemical Constituents:-}

A number of chemical constituents were reported from the plant tridax procumbens viz: Alkaloids, flavanoids, cartenoids, beta-sitisterol, n-hexane, fumaric acid, luteolin, quercitin, Oxoester, lauric acid, myristic, palmitic, arachidic, linoelic acid and tannin etc. Earlier Workers have reported presence of dexamethasone, luteolin, glucoluteolin, betasitosterol and Quercitin,(21), (22). linoelic acid was also reported in the aerial parts. A new flavanoid 'procumbenetin isolated from aerial parts of plant, has been characterized as 3,6- dimethoxy-5, 7, 2', 3', 4'-pentahydroxyflavone 7- o-beta-glucopyranoside. Mineral composition of T. Procumbens reported from leaves is calcium, magnesium, potassium, sodium and selenium. It has been observed that T. procumbens can serve as a good source of plant protein and Potassium supplement, as well as being potential source of provitamin A (cartenoids) to the Population four new terpenoids along with bis-bithiphene were reported from T. Procumbens: taraxasteryl acetate, beta-amyrenone, lupeol and oleonic acid. Two new Flavones, 8, 3'-dihydroxy -3,7,4'-trimethoxy-6-o-betaD-glucopyranosal flavone(1) and 6,8,3'-trihydroxy-3,7,4'-trimethoxy flavone (2) were isolated from tridax procumbens linn., Together with the four known compounds puerarin(3), esculetin(4), olenolic acid (5) and Betulinic acid (6).

The plant yielded intresting compounds like luteolin, beta-amyrin, beta-amyron, lupeol, tri contanol, fucosterol, campesterol, stigma sterol, besides arachidic acid, lauric acid, palmitic acid, flavones and glycosides.

\section{Antifungal Activity Of The Three Extracts Of Tridax Procumbens :-.}

The fungal was determined by measuring the diameter of zone of inhibition recorded. Ethyl acetate extract of tridax procumbens L. Was found to be have maximum antifungl activity in comparision ethanolic and aqueous extracts. Ethyl acetate extract possessed potent antifungal activity against candida albicians showing diameter of zone inhibition viz. $20 \mathrm{~mm}$ while ethanoic extracts showed less antifungal activit against aspergillus flavus and aspergillus nigar showing diameter of zone 0of inhibition viz, $12 \mathrm{~mm}$ and $18 \mathrm{~mm}$ respectively. Ethyl acetate extract possessed potent antifungal activity against candida albicans showing diameter of zone of inhibition viz., $12 \mathrm{~mm}$ and $7 \mathrm{~mm}$ respectively. ethyl acetate extract possessed potent antifungal activity against candida albcians showing diameter of zone of inhibition viz $12 \mathrm{~mm}$ while ethanolic extract showed less fungal activity against aspergillus flavus and aspergilus niger showing diameter of zone of inhibition viz. $10 \mathrm{~mm}$ and $7 \mathrm{~mm}$ respectively.

Anti fungal activity of the three extracts of tridax procumbens $L$ :-

\begin{tabular}{|c|c|c|c|c|c|}
\hline S.no & Solvent extract & Organism & $\begin{array}{c}\text { Diameter of zone } \\
\text { inhibition }(\mathbf{m m})\end{array}$ & Mic(mg/ml) & Mfc(mg/ml) \\
\hline 1 & EAE & Candida albicans, & 20 & 0.6 & 0.8 \\
\hline 2 & EE & - & 12 & 0.7 & 0.9 \\
\hline 3 & AE & - & 8 & 0.9 & 1.2 \\
\hline 4 & EAE & Aspergallus flavus & 18 & 0.5 & 0.7 \\
\hline 5 & EE & - & 12 & 0.7 & 1.0 \\
\hline 6 & AE & - & 7 & 0.9 & 1.1 \\
\hline 7 & EAE & A.niger & 12 & 0.6 & 0.8 \\
\hline
\end{tabular}

\section{Various Pharmacological Activities Of Tridax Procumbens L:- Wound Healing:-}

Leaf juice of tridax procumbens was shown to express wound contraction in experimental animals. Tridax antagonised antiepithelization and tensile strength depressing effect of dexamethasone (a known healing suppressant agent) without effecting anticontraction and antigranulation action of dexamethasone. Aqueous extract was also effective in increasing lysyl oxidase but to a lesser degree than whole plant extract. Further it has been show that extract of leaves of this plant also promotes wound healing in both normal and immune compromised (steroid treated) rats, the plant increase not only lysyl oxidase but also, protein and nucleic acid content in the granulation tissue, probably as a result of increase in glycosaminoglycan content. 


\section{Hepatoprotective:-}

The hepatoprotective activity of aerial parts of tridax procumbens was investigated against d-galactosaminel lipopolysaccharide (d-GalN/LPS) included hepatitis in Rats.DGa1N/LPS have been proposed to be hepatotoxic due to its stability to destruct liver cells. The multifocal necrosis produced by DGa1N and the lesion of viral hepatitis in humans are similar. This amino sugar is known to selectively block the transcription and indirectly hepatic protein synthesis and as consequence of endotoxin toxicity, it contains fulminate hepatitis within 8 hour administration.

\section{Anti-Diabetic:-}

Masdhumeha another name of diabetis in which patient passes sweet urine And exhibits sweetness all over the body in the form of sugar, i.e. in sweat, mucous, urine, blood, etc. from ancient time various herbs were practically used for lowering of blood glucose level as such or in juices form. Aqueous and alcoholic extract of leaves of tridax showed a significant decrease in the blood glucose level in the model alloxan-induced diabetes in rats.

\section{Antimicrobial Activity:-}

Whole plant of tridax has reported for its antimicrobial activity on various species of bacteria. A whole plant is squeezed between the palms of hands to obtain juice. Fresh plant juice is applied twice a dayfor 3-4 days to cure cuts and wounds. The extract of whole plant of tridax showed antibacterial activity only against pseudomonas aerugeniosa. The disk diffusion method was used to test antimicrobial activity. Four strains of bacteria employeed in test were two-gram positive bacillus subtitles', staphylococcus aureus and two gram negative Escherichia coli and pseudomonas aeruginosa.

\section{Anti-Cancerous Activity:-}

The effect of cancer activity of traditionally plant tridax procumbens flower crude aqueous and acetone extract was tested on prostate epithelial cancerous cells PC 3 was determined by measuring cell viability.Experiment consists of cleavage of the soluble yellow coloured tetrazolium salt MTT [3-(4,5-dimethyl -thiazole-2-yl)-2,5-diphenyl tetrazolium bromide] to a blue coloured formazan by the mitochondrial succinate dehydrogenase the assay was based on the capacity of mitochondrial enzymes of viable cells to reduce the yellow soluble salt MTT to purple blue insoluble formazan precipitate which is then quantified spectrophotometrically at $570 \mathrm{~nm}$. The result of this analysis revealed the fact that flower crude extract has anticancer activity. Present study has been designed to determine the role of plant extracts of tridax procumbens $L$. both in aqueous and solvent extracts against pathogenic bacteria.

\section{Discussion:-}

The presence of antimicrobial substance in the higher plants in well established. Plants have provided a source of inspiration for novel drug compounds as plants derived medicines have made significant contribution towards human health. Phytomedicine can be used for the treatment of diseases as done in case of unani and ayurtvedic system of medicines of it can be the base for the development of a medicine, a natural blue print for the development of a drug [17]. Successive isolation of botanical compounds from plant material is largely dependent on the type of solvent used in the extraction procedure. The traditional healers use primarily water as the solvent but we found in this study the plant extracts by ethanol and methanol provided more consistent antifungal activity compared to those extracted by water. According to this study plant based antibacterial drug have enormous therapeutic potential as they can serve the purpose with lesser side effects that are often associated with synthetic antimicrobial agents. Naturally, the biological active compounds whose activity can be enhanced in the presence of ethanol and methanol could have been produced number of active compound responsible for antimicrobial activity. Essential oils are 'essences' and flavonoids are highly concentrated substances extracted from variopus parts of aromatic plants and trees. Unlike ordinary vegetable oils, such as corn and olive, plants essences are highly volatile and will evaporate if left in the open air. Essential oil is endowed with antiseptic, antibacterial, antibiotic, antidepressant, analgesic, decongestant and sedative properties. Moreover, due their tiny molecular structure, essential oils applied to the skin can be absorbed into the bloodstream. They also reach the blood as a result of the aromatic molecules being inhaled. In the lungs, they pass through the tiny air sacs to the surrounding blood capillaries by the process of diffusion. The essential oils produced by the plants have been used traditionally for the respiratory tract infections and in the recent centuries the oils are used as ethical medicines for cold and microbial infections. By inhaling the vapours of the essential oil its shows the greater output of respiratory fluid and hence it is used in treating acute and chronic bronchitis, acute sinusitis and has an anti inflammatory effect on trachea and reduced asthma. Earlier researchers reports that alpha- and beta-pinenes are active against yeast and bacteria and this mechanism lies mainly in their capacity to indace toxic effects on the membrane structure and functions. More over, alpha-pinenes are used against mushrooms and yeasts(dermatopytes), especially on candida albicians and other related species such as candida 
tropicalis, C.glabrat etc. the beta-pinenes also show antifungal properties,especially on candida spp. Studies have comfirmed that the essential oil which is rich in alpha-pinene shows a potential anti-bacterial and anti-fungal activity. Major components of our plant tridax procumbens L. was employeed using/mixing with aqueous for treating the antibacterial and other infections. In our study, we found that the tridax procumbens also contains the same compound as its major compound and the activity shown by the essential oil may also be due to the presence of these terpenes as its major compounds and other flavonoids. The anti fungal activity was determined by measuring the diameter of zone of inhibition recorded. Ethyl acetate extract of tridax procumbens L. was found to have maximum antifungal activity in comparsiopn ethanolic and aqueous extracts. Ethyl acetate extract possessed potent antifungal against candida albicians showing diameter of zone of inhibition viz. 20mm while ethanolic extract showed less fungal activity against asperigillus flavus and asperigillus niger showing diameter of zone of inhibition viz. $12 \mathrm{~mm}$ and $7 \mathrm{~mm}$ respectively. Ethyl acetate extract possessed potent antifungal activity candida albicians showing diameter of zone of inhibition viz. $12 \mathrm{~mm}$ while ethanolic extract showed less fungal activity against asperigillus flavus and asperigillus niger showing diameter of zone of inhibition viz. $10 \mathrm{~mm}$ and $7 \mathrm{~mm}$ respectively. The present studty thus stated that, ethyl acetate extract of tridax procumbens.L was found to have maximum antifungal activity in comparsion ethanolic and aqeous extracts and the plant is effective against fungal infections caused by candida albicians in comparsion to asperigillus niger. Presence of chemical compounds viz, alkaloids, tannins, flavonoids and saponins of tridax procumbens L.

may inhibit the fungal growth, the present study provides the scientific information about the plant extract of tridax procumbens $L$. and supports the usage of this plant for curing fungal diseases by traditional healers. Further, phytochemical separation and immunological studies of this plant is in under progress.

\section{Conclusion:-}

The essential oil and flavanoids of tridax procumbens has a number of properties that are beneficial to human health and well being. It may be used in the pharmaceutical and cosmetic industries for the development of new drug formulation for treating bacterial and fungal infections and also for treating inflammation related diseases in a cheaper rate with fewer side effects. The results of this study have shown that the ethyl acetate and ethanolic extracts obtained from the tridax procumbens were active against atleast one of the opportunistic fungi the results of this study have shown that the leaf and whole plant extraction of tridax procumbens L. have great potential as antibacterial agent in the treatment of infectious organisms. Further, detailed investigation of the active compounds of the plant for the extract mechanism of action will contribute greatly to the development new pharmaceuticals

\section{References:-}

1. Shindesl, junne SB, Wadje SS and Baig MMV. The diversity of antibacterial componds of Terminalia species (combretaceae. Pakisthan journal of biological science 2009:12:1483-1486

2. Ahmadj 1 and Aqil $F$.:in vitro efficacy of bio active extracts of 15 medicinal plant against ESBL- producing multi drug resistant enteric bacteria. Microbiology research 2006; 162 (3): 264-275

3. Makinde AA, igoli JO tama L, shalba JJ, and barba Antimicrobial activity of cassia alata, africian journal of biotechnology 2007:6 (13): 1509-1510.

4. Ajaji A O and Akintola T.A evaluation of antibacterial activity on some medicinal plants on common enteric food borne pathogens. African journal of microbiology research 2010:4(4): 314-316

5. Jain P, Bansal D and Bhasin P. Antibacterial activity of aqueous plant extracts against Escherichia coli and bacillus substilis. Drug invention today 2009: 2(4): 220-222

6. Swaminathan ms. Inaugural address, first botanical conference 1975, meerut, india p: 1-31

7. Nia.R.,E.E., Investigation into in invitro radical scavenging and in vivo anti-inflammatory potential of tridax procumbens Nigerian journal of physiological sciences. 2000; 18(10: 39-43

8. Habila. J.D., Bello.I.A., Dzikwi. A.A, Total phemolics and antioxidant activity of tridax procumbens. Linn. African journal of pharmacy and pharmacology. 2010;4(3):123-126

9. Sneha mundada., Ruchi shivahare ., Pharmacology of tridax procumbens a weed Review international journal of pharm tech research .2010;2(2):1391-1394

10. Sharma. B., Kumar .P., Extraction and pharmacological evaluation of some extracts of tridax procumbens and capparris deciduas.2009;1(4):5-12

11. Ikewuchi jude., ikewuchi Catherine.C., international journal of applied research in natural products, chemical profile of tridax procumbens linn. Pakistan journal of nutrition.2009;(5):548-550 
12. Manjamalai.A, V.M. berlin grace, analysis of phyto chemical constituents and anti microbial activity of some medical plants in tamil nadu, india. Global journal of biotechnology\&biochemistry. 2010;5(2):120-128

13. Shatish kumar.k., extracting of essential oil using steam distillation. Institute of technology (B-tech project).2010:p:1-33.

14. Sarfaraz khan marwat, Muhammad aslam khan., aromatic plant species mentioned in the holy quran and ahadith and their ethno medical importance, Pakistan journal of nutrition.2009;8(9):1472-1479.

15. Pandy,D., raovirendra.p.s., extraction of essential oil from eucalyptus leaves;(B-tech project);NIT-rourkela.

16. Amr E., edris-pharmaceutical and therapeutic potential of essential oils and their individual volatile constituents; a review pytotherapy research,2007.

17. Saini A, wadhwani c, kaur B and malik C P, tissue culture studies in tridax procumbens. Journal plant sciences. Res.24:85-88,(2008).

18. Chauhan B S and germination D E, ecology of two troublesome asteraceae species of rainfed rice: siam weed (chromolaena odourata ) and coat buttons (tridax procumbens) jhonson weed science 56:567-573,(2008).

19. Khan S.K, rahman A.H.M.M, alam M.S,ahmed ferdous, Rahul islam A.K.M, and rahman M. Matiur, taxanomic studies on the family asteraceae (compositae) of the rajashahi division. Research journal of agriculture and biological sciences, 4(2):134-140 (2008).

20. Singh $\mathrm{k}$ and ahirwar $\mathrm{v}$, acute and chronic toxicity study of tridax procumbens on haemoglobin percent and blood sugar level of Sprague dawley rats. Ijpi's journal of pharmacology and toxicology. 1(1): 1-6(2010).

21. Reddy setharami TVV, prasanthi S, and naidu ramarao BVA traditional phytherapy for jaundice in herbal medicine (ed) PC trivedi aavishkar publishers, Jaipur, pp: 30-68,(2006).

22. Subramanian SS, ramakrishnan S, and nair AGR, isolation of luteolin and glucolutyeolin from the flowers of tridax procumbens. Curr. Sci. 37:465-469(1968).

23. Raju TS and Davidson E A, structural feature of water soluble novel polysaccharide components from leaves of tridax procumbens linn. 258:243-54,(1994).

24. Chen, wen-hao; ma, xing - ming ; wu, quan- xiang; shi, and yan- ping, chemical constituents diversity of tridax procumbens. Candian journal of chemistry, 86(9):892-898(7),(2008).

25. Jude C. Ikewuchi, Catherine C. Ikewunchi and ngozi gboh M. I, chemical profile of tridax procumbens linn, Pakistan journal of nutrition,8(5):548-550,(2009).

26. Ali M.S, and Jahangir MA, bis-bithiphene from tridax procumbensl. (asteraceae), nat prod let., 16(4):21721,(2002).22. Runsheg xu, jing zhang and ke yaun, two flavones from tridax procumbens linn. Molecules, 15:6357-6364,(2010).

27. Verma R.K and gupta M.M, lipid constituents of tridax procumbens. Phytochemistry 27(2):459-163,(1998).

28. Ali M.S, Jahangir M, hussain S, and choudhary M, inhibition of a-glucosidase by oleanolic acid and its synthetic derivatives.phytochemistry,60:295-299,(2002).

29. Bushra beegum NR and ganga devi T: antibacterial activity of selected sea weeds from kovalam south west coast of india. Asian journal microbial biotech env sci 2003; 5(3):319-322.

30. Bonjar GHS, farrokhi PR: antibacillus activity of someplants used in traditional medicine of iran. Niger $\mathrm{j}$ nat proc med 2004;8:34-39.

31. Jalapure SS, patil MB, aruna $\mathrm{P}$, shah $\mathrm{B}$, salahuddin MD: antidiabetic activity of cassia airiculata seeds in alloxan induced diabetic in rats. Niger $\mathrm{j}$ nat proc med 2004; 8:22-23.

32. Fias A AL-bayati and Hassan F AL-mola: antibacterial and antigungal activities of different parts of tribulus terrestris L. Growing in Iraq. J zhehiang univ sci 2008;9(2):154-159.

33. Bibi SFB, mehrangizk $\mathrm{K}$ and hamid RS : in vitro antibacterial activity of rheum ribes extract obtained from the various plant parts against clinical isolates of gramnegative pathogens. Irranian $\mathrm{j}$ of pharmaceutical research 2005;2:87-91.

34. Castello MC, phatak A, Chandra N, Sharon M ; antimicrobial activity of crude extracts from plant parts and corresponding cali of bixa orellana L. Indian j exp boil 2002;40(12):1378-1381.

35. Ali $\mathrm{M}$, rawinder $\mathrm{E}$ and ramachandram $\mathrm{R}$; A new flavonoid from the aerial parts of tridax procumbens $\mathrm{L}$. Fitoterapia 2001;72:313-315.

36. 36. Saraf S, pathak AK, dixit VK: hair growth promoting activity of tridax procumbens L. Fitoterapia 1991;62:495-498.

37. Pathak AK, saraf S dixit VK: hepato protective activity of tridax procumbens 1. Part,1. Fitoterapia 1991;62:495-498.

38. Ravi kumar V, kanchi Subramanian shivashangiri and devaki T: effect of tridax procumbens 1 . A lives anti oxidant defense system during lipopoly saccharide - induced hepatitis in d-galactosamine sensitized rats. Molecular and cellular biochemistry 2005; 269 131-136. 